\title{
Biological invasion of imported cabbageworm, Pieris rapae (L.), on oilseed Brassica in Punjab, India
}

\author{
Sarwan Kumar \\ Department of Plant Breeding and Genetics, Punjab Agricultural University, Ludhiana-141 004, India
}

Email address:

sarwanent@pau.edu

\section{To cite this article:}

Sarwan Kumar. Biological Invasion of Imported Cabbageworm, Pieris rapae (L.), on Oilseed Brassica in Punjab, India. American Journal of Agriculture and Forestry. Vol. 2, No. 6, 2014, pp. 274-277. doi: 10.11648/j.ajaf.20140206.17

\begin{abstract}
The infestation of imported cabbageworm/ small white butterfly, Pieris rapae (L.) (Lepidoptera: Pieridae) is reported on oilseed Brassica rapa ssp. oleifera, ecotype brown sarson cv. BSH 1 from Punjab, India. Though, it has been reported earlier on vegetable brassicas in India, there is no report of its infestation on oilseed brassica in this part of the country so far. A low infestation of 1.7-3.3 larvae per 10 plants was reported during first to third Standard Meteorological Week of 2014. Since this pest has potential to cause significant damage to oilseed brassica crops, therefore, timely reporting of this pest is important to avoid any future outbreak.
\end{abstract}

Keywords: Cabbage Caterpillar, Oilseed Brassica, Small White Butterfly

\section{Introduction}

Rapeseed-mustard is an important group of winter season oilseed crops after soybean (Glycine max (L.) and Palm (Elaeis guineensis Jacq.) oil. India is one of the leading producers including Canada, USA, European Union, Australia and China. Among the seven edible oilseed crops cultivated in India, rapeseed-mustard (Brassica spp.) contributed 26 per cent of the total oilseeds production in the year 2012-13 [23]. It is the second most important edible oilseed after groundnut sharing 27.8 per cent in the India's oilseed economy. The share of rapeseed-mustard to the total edible rabi oilseeds production was 78.9 per cent, during 2005-06 to 2010-11 [16]. In India, under the name rapeseed and mustard three cruciferous members of Brassica species are cultivated; $B$. juncea (Indian mustard or commonly called rai) being the chief oil yielding crop, while three ecotypes of $B$. rapa ssp. oleifera, viz. brown sarson, yellow sarson, toria and $B$. napus are grown to a limited extent [2].

The average productivity of India $(1176 \mathrm{~kg} / \mathrm{ha})$ is about two-third of world's average yield of $1695 \mathrm{~kg} / \mathrm{ha}$ [26]. There are many reasons for this low yield, among which the damage caused by insect-pests is the one. A number of insect-pests are associated with this group of crops right from sowing till harvest. The pest complex of oilseed Brassica in this part of the country is witnessing a change possibly due to climate change, intensive cultivation of high yielding varieties, frequent and indiscriminate application of synthetic insecticides, development of insecticide resistance in insects. The changing scenario of insect pest problems in agriculture as a consequence of green revolution has been well documented $[8,9]$. The pest complexes have changed to the extent that some of the insects which had been known earlier to be sporadic, minor or non-injurious to these crops, have become serious pests in certain agroclimatic conditions today, whereas, other insects which were never previously recorded on these crops are now becoming a matter of concern [25]. For example, the large white butterfly, Pieris brassicae (L.) (Lepidoptera: Pieridae) which was once a sporadic pest of oilseed Brassica has become a regular pest of oilseed Brassica [17] in this region and is one among the important pests after turnip aphid, Lipaphis erysimi (Kaltenbach) (Homoptera: Aphididae). The objective of the present study is to report a new pest Pieris rapae for the first time on oilseed Brassica crops in Punjab province of India.

\section{Materials and Methods}

Field experiment was conducted during November 2013 to March 2014 at Punjab Agricultural University, Ludhiana $\left(30^{\circ}\right.$ $56^{\prime} \mathrm{N}, 75^{\circ} 52^{\prime} \mathrm{E}, 247 \mathrm{~m}$ above mean sea level), India to study the population dynamics of insect-pests infesting oilseed Brassica crops. The climate of the area is characterized as sub-tropical and semi-arid with hot and dry spring summer 
from April to June, hot and humid summer from July to September and cold autumn winter from November to January. The average annual rainfall is about $700 \mathrm{~mm}$, most of which is received during monsoon period from July to September with little showers during winter (crop) season. The soil of the experimental field was loamy sand in texture having $\mathrm{pH}$ 7.5. The experiment was laid out in a randomized complete block design with three replications of 10 cultivars. The different cultivars included; Brassica juncea: RLC 1 (single '0' i.e. low erucic acid), PBR 91, PBR 210 (both conventional i.e. high in erucic acid and glucosinolates)); B. napus: GSC 6, GSC 5 (both '00' i.e. canola), GSL 1, GSL 2 (both conventional); $B$. carinata: PC 5 (conventional), B. rapa ssp. oleifera ecotype brown sarson cv. BSH 1 (conventional); and Eruca sativa: T 27 (conventional) (all available from Incharge, Oilseeds Section, Department of Plant Breeding and Genetics, Punjab Agricultural University, Ludhiana - 141 004, Punjab, India except T 27 which is available from Director, Directorate of Rapeseed-Mustard Research, Bharatpur - 321 303, Rajasthan, India). All the cultivars were sown on November 9, 2013 in plots of size $4.2 \times 3 \mathrm{~m}$ with recommended package of practices [19] except spray of insecticides. Sowing was delayed by 19 days than normal since late sown crop is heavily attacked by insect pests in this part of the country [15]. All the 10 cultivars were sown in well prepared seed beds with the help of seed drill. The row to row and plant to plant spacing was maintained at $30 \mathrm{~cm}$ and $15 \mathrm{~cm}$, respectively, for all the Brassica species except B. napus for which it was $45 \mathrm{~cm}$ and 15 , respectively. A basal dose of $50 \mathrm{~kg} \mathrm{~N}$ (as urea) and $30 \mathrm{~kg}$ phosphorous $\mathrm{ha}^{-1}$ (as single super phosphate) was applied at sowing time and $50 \mathrm{~kg} \mathrm{~N} \mathrm{ha}{ }^{-1}$ was applied three weeks thereafter at the time of first irrigation. After about four weeks of sowing, when the plants reached true leaf stage, data on the population of different insect-pets were recorded in each cultivar from 10 plants selected at random at weekly intervals. Since, the present paper describes the first record of imported cabbageworm on oilseed Brassica in this region, the data on other insect pests are not presented here. Larvae of $P$. rapae were collected and maintained individually in laboratory in a styrofoam cup covered with a fine muslin cloth fastened with elastic bands in a Biological Oxygen Demand (B.O.D.) incubator at $22 \pm 1^{\circ} \mathrm{C}$ till pupation and subsequent adult eclosion.

\section{Results and Discussion}

A very low incidence of imported cabbageworm, $P$. rapae was recorded on B. rapa ssp. oleifera ecotype brown sarson cv. BSH 1 at experimental farm in Ludhiana, Punjab, India, during 1-3 Standard Meteorological Week (SMW) of 2014, which ranged from 1.7 to 3.3 larvae per 10 plants (Table 1). The larvae were found feeding on leaves of BSH 1. They were hard to locate on leaves since their green colour provided excellent camouflage. Damage to host plants consisted of irregular large holes on the leaf lamina (Fig. 3). During all the observations larvae were found feeding exposed on the leaf surface. Caterpillars were velvetty green with yellow lines on the body one on the dorsal side and others often broken on the lateral sides (Fig. $1 \& 2$ ). To confirm the species identification from adult stage, larvae were reared on the same host till adult eclosion from pupae. Adult butterflies that emerged from pupae had a wing span of about $43 \mathrm{~mm}$. The wings were white with black tips of forewings. There were two black spots on the top of forewing of female while males had only one such spot. A black spot was also present on the black outer margin of hind wing which otherwise is white.

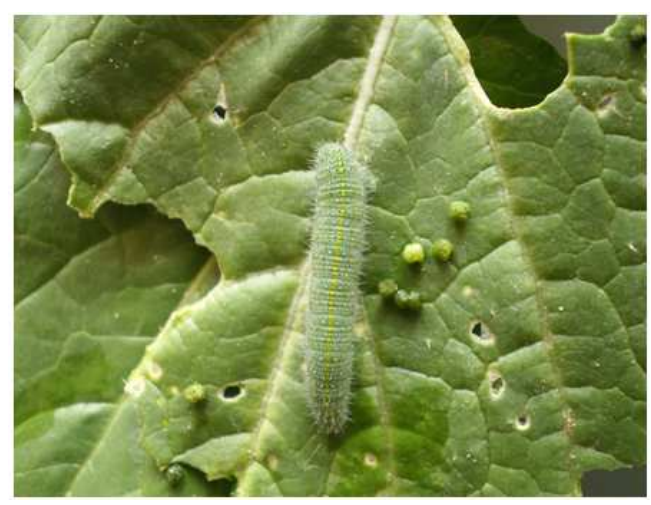

Fig. 1. Larva feeding on Brassica rapa ssp. oleifera ecotype brown sarson $c v$. BSH 1 leaf

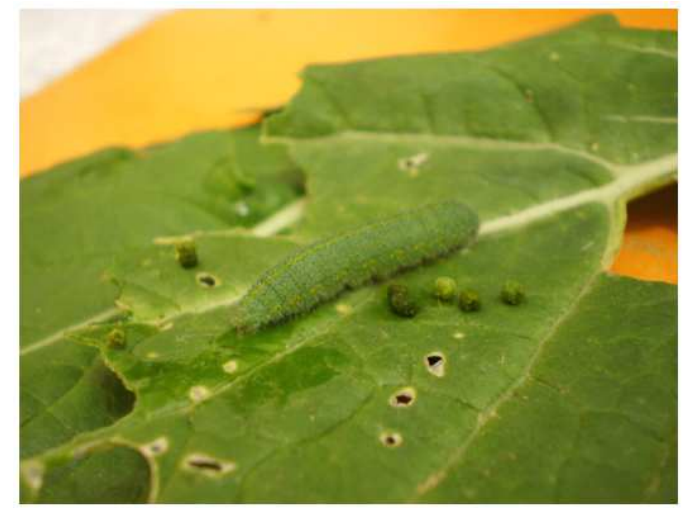

Fig. 2. Dorsal and lateral yellow lines on the larval body

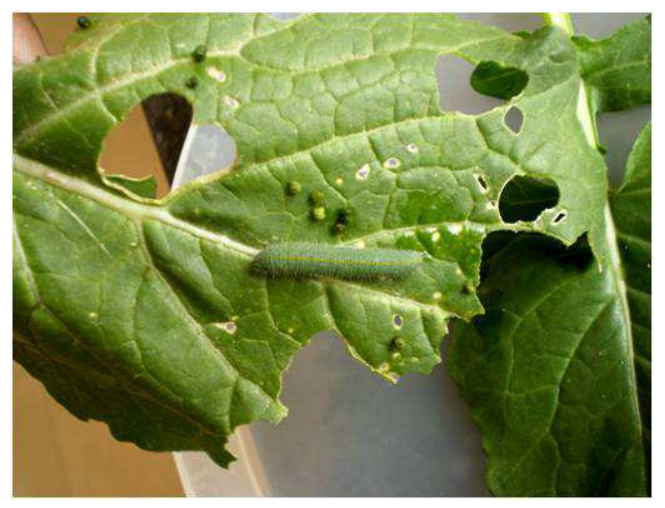

Fig. 3. Damage symptoms after larval feeding

The imported cabbage worm, Pieris rapae (L.) (Order: Lepidoptera; Sub order: Papilionoidea; Family: Pieridae; Subfamily: Pierinae; Genus; Pieris; Species; rapae (Linnaeus 1758); Synonymy: Artogeia rapae (L.) (Lepidoptera: Pieridae) 
is thought to be originated in Europe [21], where it is called the small white butterfly to distinguish it from Pieris brassicae, the large white. It has spread around the world in the wake of European colonization. It was first found outside Europe in Canada in 1860 when it was accidently introduced to Quebec which later spread throughout North America [13] and subsequently to Hawaii and Australia as well [3].

Unlike the larvae of $P$. brassicae, the large white butterfly, which are found in gregarious phase during initial stages of their development (first three instars), P. rapae larvae were found solitary feeding on the leaves. Though females lay eggs singly, their fecundity is very high and a single female can lay on an average 300-400 eggs which can go as high as 1000/ female [14]. Although, the damage caused by P. rapae was slight, but it can be severe in years with high infestation [12]. $P$. rapae is an economically important pest of brassica vegetables the world over. Some of its host plants include: broccoli, Brussels sprouts, cabbage, cauliflower, Chinese broccoli, Chinese cabbage, choy sum, collards, daikon, horseradish, kale, kohlrabi, mustard, mustard cabbage (kaichoy), pak choy, radish and turnip. It may also feed on other plants such as nasturtium, lettuce and sweet alyssum. In addition to these, Shepherd's purse is a weed host of this pest. To date this insect has not been reported to infest oilseed Brassica crops in Punjab province of India though it is reported as a pest of vegetables (cabbage and cauliflower) in other parts of the country [27, 1]. In India, it has been primarily documented as a pest of vegetable Brassica $[4,10]$. Even in other parts of the world also, it is documented as a pest of vegetables [5]. It has shown considerable potential to expand its geographical distribution from Europe to other parts of the world and host plant range. It is likely that $P$. rapae can pose a serious threat to oilseed Brassica crops in this geographical region, which can lead to extensive insecticide use potentially causing multitude of undesirable side-effects [28, 7]. Development of an effective management strategy at this early stage of detection is important in order to prevent its damage to these important winter season oilseed crops of India.

Invasive species like $P$. rapae represent a major threat to both natural [6, 22] and agricultural [18, 11, 24, 20] ecosystems. They can reduce crop yields, increase costs (related to their management), and lead to the use of pesticides which ultimately lead to disruption of existing pest management systems [26]. Thus, monitoring and timely reporting of this pest is important to avoid any future outbreak on oilseed Brassica. There is a need of detailed study of its biology, bionomics and population dynamics on different oleiferous Brassica so that management strategy can be devised well in time before it reaches serious proportions.

\section{References}

[1] Bhat D. M., and R. C. Bhagat (2009) Natural parasitism of Pieris rapae (L.) and Pontia daplidice (L.) (Lepidoptera: Pieridae) on cruciferous crops in Kashmir Valley (India). American Eurasian J. Agric. Environ. Sci. 5: 590-591.
[2] Bhatia V., P. L. Uniyal and R. C. Bhattacharya (2011) Aphid resistance in Brassica crops: challenges, biotechnological progress and emerging possibilities. Biotechnol. Adv. 29: 879-888. doi:10.1016/j.biotechadv.2011.07.005

[3] Braby M. F. (2000) Butterflies of Australia. CSIRO Publishing, Melbourne, vol. 1: 343-344.

[4] Butani D. K. and M. G. Jotwani (1984) Insects in vegetables. Delhi, India: Periodical Expert Book Agency, 356p.

[5] Capinera J. L. (2001) Handbook of vegetable pests. California, USA: Academic Press, 729p.

[6] Clavero M. and E. Garcia-Berthou (2005) Invasive species are a leading cause of animal extinctions. Trends Ecol. Evol. 20: 110 .

[7] Desneux N, A. Decourtye and J. M. Delpuech (2007) The sublethal effects of pesticides on beneficial arthropods. Ann. Rev. Entomol. 52: 81-106.

[8] Dhaliwal G. S. and R. Arora (2006) Integrated pest management: concepts and approaches. New Delhi, India: Kalyani Publishers.

[9] Dhaliwal G. S. And O. Koul (2010) Quest for pest management: From green revolution to gene revolution. New Delhi, India: Kalyani Publishers.

[10] Gupta S. L. (1990) Key for the identity of some major lepidopterous pests of vegetables in India. Bull. Entomol. 31: 69-84.

[11] Haack, R. A., F. Herard, J. H. Sun, and J. J. Turgeon (2010) Managing invasive populations of Asian longhorned beetle and citrus longhorned beetle: a worldwide perspective. Ann. Rev. Entomol. 55: 521-546.

[12] Hern, A., G. Edwards-Jones and R. G. McKinlay (1996) A review of the preoviposition behaviour of small cabbage white butterfly Pieris rapae (Lepidoptera: Pieridae). Annals appl. Biol. 128: 349-371.

[13] Howe W. H. (1975) The butterflies of North America. Doubleday, Garden City, 633p.

[14] Jogar K, L. Metspalu, K. Hiiesaar, A. Ploomi, E. Svilponis, A. Kuusik, N. Menshykova, I. Kivimagi and A. Luik (2009) Influence of white cabbage cultivars on oviposition preference of the Pieris rapae L. (Lepidoptera: Pieridae). Agronomy Res. 7 (Spl. Issue I): 283-288.

[15] Kular, J. S., A. S. Brar, and S. Kumar (2012) Population development of turnip aphid Lipaphis erysimi (Kaltenbach, 1843) (Hemiptera: Aphididae) and the associated predator Coccinella septempunctata Linnaeus, 1758 as affected by changes in sowing dates of oilseed Brassica. Entomotropica 27: 19-25.

[16] Kumar, A (2012) Production barriers and technological options for sustainable production of rapeseed-mustard in India. J. Oilseeds Brassica 3: 67-77.

[17] Kumar, S. (2011) Cotesia glomeratus - a potential biocontrol agent for large white butterfly Pieris brassicae in Indian Punjab. Proceedings of $13^{\text {th }}$ International Rapeseed Congress, Prague, Czech Republic, June 05-09, 2011. vol. 13, pp. 1141-43.

[18] Olson, L. J. (2006) The economics of terrestrial invasive species: a review of the literature. Agric. Resources Econ. Rev. 35: 178-194. 
[19] PAU (2013) Package of Practices for Crops of Punjab: Rabi 2013-14. Punjab Agricultural University, Ludhiana, India, pp. 43-53.

[20] Ragsdale, D. W., D. A. Landis, J. Brodeur, G. E. Heimpel and N Desneux (2011) Ecology and management of the soybean aphid in North America. Ann. Rev. Entomol. 56: 375-399.

[21] Robbins, R. K. and P. M. Henson (1986) Why Pieris rapae is a better name than Artogeia rapae (Pieridae). J. Lepidopterists' Society 40: 79-92.

[22] Samways M. J. (2007) Insect conservation: a synthetic management approach. Ann. Rev. Entomol. 52: 465-487.

[23] Singh D. (2014) Genetic enhancement of mustard for seed yield and its sustainability. In: V. Kumar, P. D. Meena, D. Singh, S. Banga, V. Sardana and S. S. Banaga, 2014: Abstracts, $2^{\text {nd }}$ National Brassica Conference on 'Brassicas for Addressing Edible Oil and Nutritional Security' organized by Society for Rapeseed Mustard Research, Bharatpur, India at Punjab
Agricultural University, Ludhiana, India during Feb. 14-16, 2014, p. 18

[24] Suckling, D. M. and E. G. Brockerhoff (2010) Invasion biology, ecology, and management of the light brown apple moth (Tortricidae). Ann. Rev. Entomol. 55: 285-306.

[25] Taggar, G. K., R. Singh, R. Kumar and P. C. Pathania (2012) First report of flower chafer beetle, Oxycetonia versicolor, on pigeonpea and mungbean from Punjab, India. Phytoparasitica DOI 10.1007/s12600-012-0222-8

[26] Thomas, M. B. (1999) Ecological approaches and the development of 'truly integrated' pest management. PNAS USA 96: 5944-5951.

[27] Verma, A. K. (1974) Systematic studies of the butterflies of Patiala area. M.Sc. Thesis, Punjabi University, Patiala.

[28] Weisenburger D. D. (1993) Human health: effects of agrichemicals use. Human Pathology 24: 571-576. 